\title{
SURFACE ACOUSTIC WAVES APPLICATION FOR GAS LEAKAGE DETECTION
}

\author{
Mateusz PASTERNAK ${ }^{1}$, Krzysztof JASEK ${ }^{2}$, Michal GRABKA ${ }^{2}$ \\ ${ }^{1}$ Wojskowa Akademia Techniczna, Wydział Elektroniki, mateusz.pasternak@wat.edu.pl \\ ${ }^{2}$ Wojskowa Akademia Techniczna, Wydział Nowych Technologii i Chemii, \\ krzysztof.jasek@wat.edu.pl, michal.grabka@wat.edu.pl
}

\begin{abstract}
Surface Acoustic Waves (SAW) are by their nature very sensitive to changes in physical propagation conditions. This statement relates primarily to the properties of the substrate, i.e. the surface on which these waves propagate, but under certain conditions it also refers to the parameters of the gaseous environment directly in contact with the substrate. The influence of this environment on SAW parameters can be used to detect specific gases that are present in this environment and change its density. The basic research problem was to determine the dependence of the resonant frequency and attenuation of waves in a resonator with SAW on the parameters and concentrations of specific gases in the gaseous environment in which the resonator works. The secondary objective was to determine whether this dependence is strong enough to be used for the construction of sensors and whether it is possible to identify gases present in the environment based on such measurements. Two-port resonators from SAW and measuring stand of our own design were used for the research. The analyses conducted and laboratory measurements confirmed the existence of the abovedescribed dependence. It was found that it increases with the increase of the difference between the molar mass of the gas being tested and the average molecular mass of the gaseous environment. This fact makes the proposed method suitable for detection of gases of relatively low or high molar masses. In air it is possible to detect hydrogen, helium, krypton, xenon and vapour of volatile compounds with sufficiently high molar masses.
\end{abstract}

Key words: surface acoustic waves, gas detection, diagnostic of sealing

\section{ZASTOSOWANIE AKUSTYCZNYCH FAL POWIERZCHNIOWYCH DO DETEKCJI WYCIEKU GAZÓW}

\section{Streszczenie}

Akustyczne fale powierzchniowe (AFP) są ze swej natury bardzo czułe na zmiany fizycznych warunków propagacji. Stwierdzenie to dotyczy przede wszystkim własności ich podłoża tj. powierzchni, po której te fale się propagują, jednak w pewnych warunkach odnosi się ono także do parametrów otoczenia gazowego bezpośrednio stykającego się z tym podłożem. Wpływ tego otoczenia na parametry AFP można wykorzystać do detekcji specyficznych gazów znajdujących się w tymże otoczeniu i zmieniających jego gęstość. Podstawowym problemem badawczym było określenie zależności częstotliwości rezonansowej i tłumienia fal w rezonatorze z AFP od parametrów i stężeń określonych gazów znajdujących się w otoczeniu gazowym, w którym tenże rezonator pracuje. Ustalono też czy zależność ta jest dostatecznie silna aby dało ją się wykorzystać do budowy czujników oraz czy możliwa jest na podstawie takich pomiarów identyfikacja gazów obecnych w otoczeniu. Do badań wykorzystano dwuportowe rezonatory z AFP oraz własnej konstrukcji stanowisko pomiarowe. Stwierdzono, że wymieniona zależność rośnie w miarę wzrostu różnicy masy molowej oznaczanego gazu od przeciętnej masy cząsteczkowej otoczenia gazowego. Fakt ten powoduje, że proponowana metoda nadaje się w do detekcji gazów o stosunkowo niskich lub wysokich masach molowych. W powietrzu można w ten sposób wykrywać wodór, hel, krypton, ksenon oraz pary lotnych związków o odpowiednio wysokiej masie molowej.

Słowa kluczowe: akustyczne fale powierzchniowe, detekcja gazów, diagnostyka uszczelnień

\section{INTRODUCTION}

Industrial technologies, diagnostic tests or laboratory work very often require the use of various industrial gases. This makes it necessary to transport and store them, as well as monitor the tightness of the containers and the installation. This is most often done by systematic pressure control, monitoring of the filling level of cylinders and tanks or by using dedicated electronic detection devices.

The most frequently used gas detectors include: catalytic, electrochemical, semiconductor, photo- 
acoustic, infrared, flame and ultrasonic. The variety of detection mechanisms used results from the existence of specific advantages and disadvantages of each of the above mentioned detectors. In many cases, only their synergistic cooperation may allow to obtain the expected detection parameters. This is the reason why, despite the existence of many detection devices, there is a constant search for new solutions. This article describes a rather innovative method for detecting leaks of technical gases based on the use of Rayleigh waves. These waves, which belong to the family of surface acoustic waves (SAW), are by their nature very sensitive to changes in physical propagation conditions. This statement concerns first of all the properties of their substrates, i.e. the near-surface layer in which the waves propagate, but under certain conditions it also refers to the parameters of the gaseous environment directly in contact with these substrates [1 - 4]. The influence of this environment on SAW parameters can be used to detect specific gases, present in this environment, and changing its density. A sensor working on this principle is not highly selective, but its advantage can be a very fast response rate and simplicity of operation. This can be important for monitoring industrial gases with toxic or explosive properties, where basically high selectivity is not required, but sensitivity, short response time and reliability are important.

\subsection{SENSOR PRINCIPLE OF OPERATION}

The Rayleigh wave can propagate in the nearsurface layer of elastic solids and is essentially a nearsurface superposition of bulk transverse and longitudinal waves that propagate away from the surface independently and at different speeds. The movement of the medium associated with the Rayleigh wave is practically non-existent at a distance of the order of the wavelength - sufficient for transverse and longitudinal waves to propagate independently.

The surface amplitude of the Rayleigh wave propagating from the point of excitation is inversely proportional to the distance $r$ from this point, much slower than for bulk waves. In the ideal case, the damping of this wave is caused by the gradual radiation of its energy to the bulk of the substrate. Waves that transmit energy from the surface wave to the substrate are called leaky waves. In this case, it will be leaky Rayleigh waves. In classical theory, the substrate borders on the vacuum. However, when it is loaded with a fluid, Scholte waves will accompany Rayleigh waves, which will be carried out in the fluid layer bordering directly the solid. Their energy will also gradually leak into the fluid. The analysis of the problem of propagation of waves generated by a point source placed on the solid-fluid boundary shows that such a source in the ideal case generates nine types of waves [5]. These waves are illustrated in Fig. 1.

The fluid load modifies Rayleigh's characteristic equation by adding an additional component responsible for the additional suppression of the waves. The mechanism of absorption of the energy of surface waves by a fluid has been described in several works [e.g. 5-8], and three types of approaches to the analysis of this problem can be noted - classical, quantum and probabilistic. Classical approaches are based on the analysis of wave equations with modified boundary conditions $[5,6]$. Quantum methods use phonon models to study the behaviour of surface waves considered as phononic streams [7, 8]. In turn, probabilistic approaches use models of velocity distribution of gas particles (atoms or molecules) and mechanisms of energy their kinetic energy gaining from the waved surface $[9,10]$.

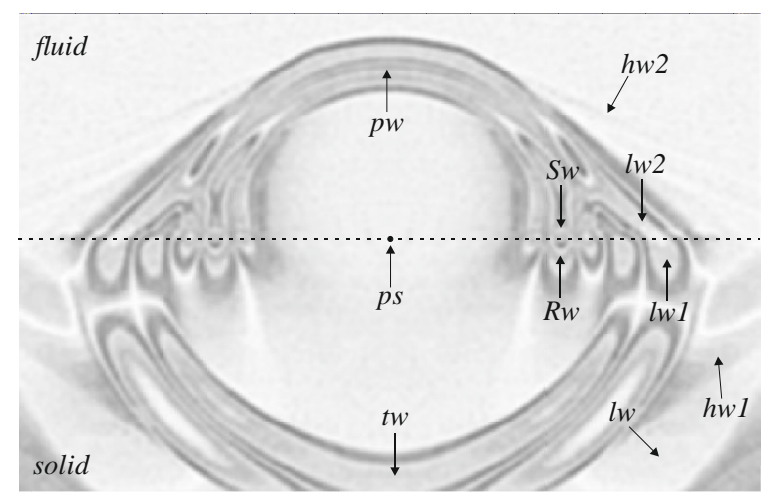

Fig. 1. Waves generated from a point source at the fluid-solid border; $l w$ - longitudinal wave in solid, $p w$ - compression wave in fluid, $t w$ - transversal wave in solid, $R w$ - Rayleigh wave, $S w$-Scholte wave, $h w 1$ - head wave in solid, $h w 2$ - head wave in fluid, $l w 1$ - leaky Rayleigh wave, $l w 2$ - leaky Scholte wave

If one assumes that a selected gas particle falls at a certain angle and with a certain energy on a surface with a Rayleigh wave, it can bounce back from that surface, taking some its kinetic energy. This is illustrated in Fig. 2.

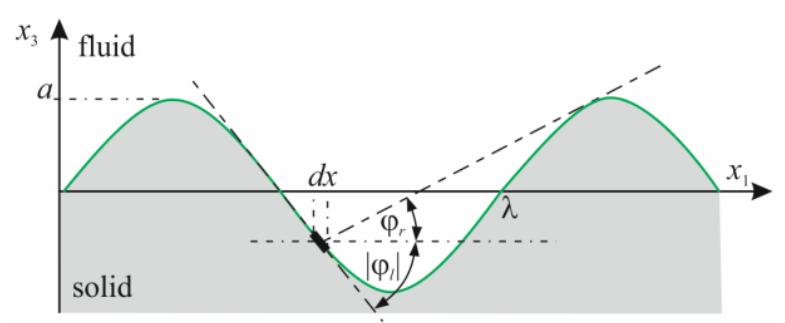

Fig. 2. A cross-section of the surface with a Rayleigh wave. The gas molecule falls on the $d x$ element at an angle of $\varphi_{r}$ and is reflected taking with it some the kinetic energy of the wave. The angles $\left|\varphi_{l}\right|$ and $\varphi_{r}$ limit the particles exit trajectories on the left and on the right respectively.

Assuming that the surface waves are sufficiently short and the temperature of the gas and substrate are similar, a statistical velocity distribution of the gas particles over the waved surface can be determined using the Maxwell model. It has the following form [10]: 


$$
\begin{aligned}
& S\left(\boldsymbol{v}, \varphi_{r}\right)=\left[\langle n\rangle+\Delta n\left(\varphi_{r}\right)\right]\left(\frac{m}{2 \pi k T}\right)^{3 / 2} \times \\
& \times \exp \left\{-\frac{m}{2 k T}\left[\left(v_{1}-u_{1}\right)^{2}+\left(v_{3}-u_{3}\right)^{2}\right]\right\},
\end{aligned}
$$

where $v_{\mathrm{i}}$ are the components of particle velocity, $u_{\mathrm{i}}$ are the components of substrate surface displacements (Rayleigh wave is assumed to be on the surface without concentrated loads - no transverse component), $\langle n\rangle$ denotes a number of molecules per unit volume increased by reflections by $\Delta n\left(\varphi_{r}\right), m$ is particle mass, $k$ is the Boltzmann constant, and $T$ is gas temperature.

This model expresses the probability density of a particles velocities. It should be noted that it is essentially correct for one- or two-atomic gases whose particles do not interact with each other. Such a condition is fulfilled in a free molecular regime.

In order for a particle to reflect from a waved surface once, the angle between the velocity vector at the moment of collision and the tangent to the waved surface cannot be arbitrary. The range of permissible angles is determined by the following reflection condition [10]:

$$
-\frac{v_{3}}{\alpha_{l}}<v_{1}-v_{R}<\frac{v_{3}}{\alpha_{r}}
$$

where the $\alpha_{l}\left(\varphi_{l}\right)=\alpha_{r}\left(2 \pi-\varphi_{r}\right), \quad \alpha_{r}=\operatorname{tg} \varphi_{r}$, $\alpha_{l}=\operatorname{tg} \varphi_{l}, v_{R}$ is the Rayleigh wave velocity. The average tangent velocity of the particle will be described using the following formula:

$$
V(\varphi)=\frac{1}{\langle n\rangle} \int_{V} v_{1} S(\boldsymbol{v}, \varphi) d \boldsymbol{v}
$$

After integration and averaging, the relationship is obtained at all angles meeting condition (2):

$$
\langle V\rangle \approx \frac{A \omega\left\langle\alpha_{r}^{*}(\varphi)\right\rangle}{2 C \sqrt{\pi}},
$$

In which the $\alpha_{r}^{*}(\varphi)=\frac{v_{R}}{A \omega} \alpha_{r}(\varphi), C=v_{R} \sqrt{\frac{m}{2 k T}}, \omega$ is the circular frequency and the $A$ is the amplitude of the Rayleigh wave. For sinusoidal surface deformation $\left\langle\alpha_{r}^{*}(\varphi)\right\rangle \approx 0,52$.

The above relationships allow to determine the kinetic energy received from the wave by the gas above it, and thus the change of the damping coefficient of the wave.

For example, for $\mathrm{LiNbO}_{3}$ substrate, Y-cut and $x_{1}$ propagation direction with an amplitude of $1 \mathrm{~nm}$, at room temperature for light gases such as helium or hydrogen, the tangential component velocity of the order of $0.1 \mathrm{~m} / \mathrm{s}$ is obtained, and for heavy gases such as krypton the value is 10 times smaller. This means that by measuring the attenuation of the Rayleigh's wave in an SAW delay line or a resonator, changes in the concentration of a given gas in the vicinity of the device can be observed. Changes in attenuation also translate into changes in wave frequency. Both of these parameters can be measured relatively easily and accurately.

\section{MEASURING SET}

The tests of the theory outlined here can be carried out using almost any system with a Rayleigh's wave device that allows easy measurement of its parameters. In general, self-excited generation systems are used for this purpose, using SAW delay lines or resonators $[11,12]$. However, these systems have the disadvantage of being only suitable for the measurement of frequency changes. It is difficult to use them for measuring changes in damping.

To carry out the measurements described herein, two-port $196 \mathrm{MHz}$ Rayleigh wave resonators [13] and measurement station of authors design were used [14, 15]. It is indeed a precise, computerized system for measuring transmission parameters, dedicated to testing two-port SAW resonators and sensors based on them. This system was used to determine the dependence of wave attenuation and resonance frequency changes in the resonator on the concentration of specific gases in the gaseous environment in which the resonator operates. In order to get rid of the effects of moisture, dried nitrogen as a carrier gas for various test gases was used. The diagram of the measuring set is shown in Fig. 3.

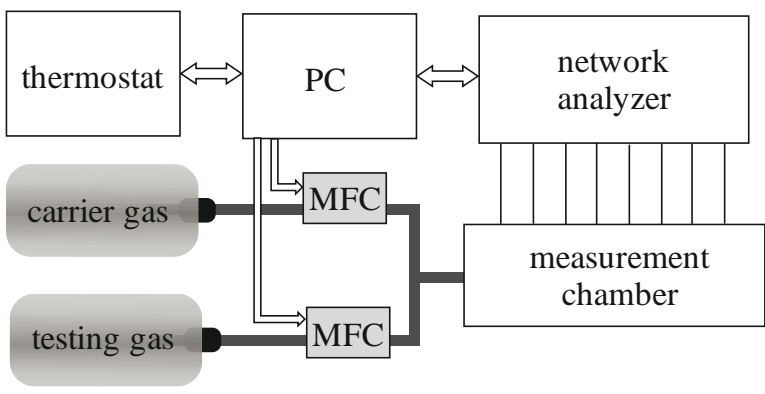

Fig. 3. Measurement system controlling the parameters of eight resonators; MFC - mass-flow controllers, PC - computing system

The part of the measuring system in contact with the test gases was thermally stabilised and ensured the stability of the temperature of the resonator chamber and the gas supply tubes at $\pm 0,5{ }^{\circ} \mathrm{C}$. The measurements were carried out at temperatures of 20 , 30,40 and $50{ }^{\circ} \mathrm{C}$

\section{MEASUREMENT RESULTS}

The measurements were carried out for four industrial gases $\mathrm{H}_{2}, \mathrm{He}$, Ar and $\mathrm{Kr}$. At a set temperature, to the measuring system nitrogen was introduced. It was a carrier gas, to which the tested gases were added in concentrations of $25 \%$ gradation. The resonators inside the chamber are used to measure the changes in amplitudes and frequencies at given concentrations. Once the system response was fixed, the measured gas was cut off. After the stabilization of 
the system containing only the carrier gas, the next concentration of the test gas, increased by $25 \%$, was introduced. The results of measurements for amplitude and frequency changes are shown in fig. 4.
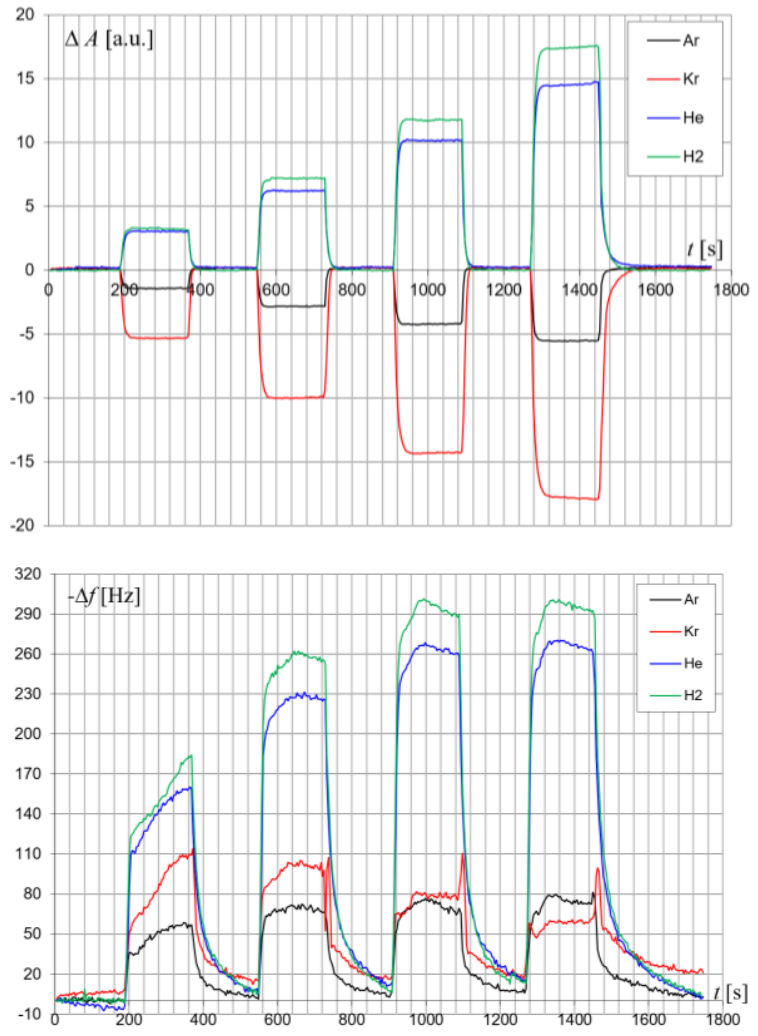

Fig. 4. An example of measured dependence of aplitude and frequency changes for different cocentrations of tested gases $(25 \%, 50 \%, 75 \%$ and $100 \%$ respectively) in nitrogen

The response time was about 40 seconds, which indicates that the surface reacts very quickly to changes in concentrations. Changes in attenuation also accompany the decrease in resonance frequency of the resonator. Since the carrier gas was nitrogen, an increase in the concentration of lighter gases results in a reduction in attenuation, while in the case of heavier gases, attenuation increases. Because in damping systems the frequency depends on the square of the damping factor, changes in this parameter will always have the same sign - the frequency will always decrease. Frequency drops at high concentrations differ slightly from the values resulting from the theory of suppressed oscillators, which indicates that there must be some additional factors involved. Perhaps it is the matter of different viscosities of the gasses. It seems that in the range of low concentrations it is more advantageous to detect frequency changes, whereas in the case of high concentrations the changes in attenuation are more visible. The detection threshold depends on difference of molar masses between carrier and detected gases.

The sensor behaves almost linearly over a wide temperature range (monitored using $\mathrm{Pt} 100$ sensor), which is shown in in fig. 5 for He.

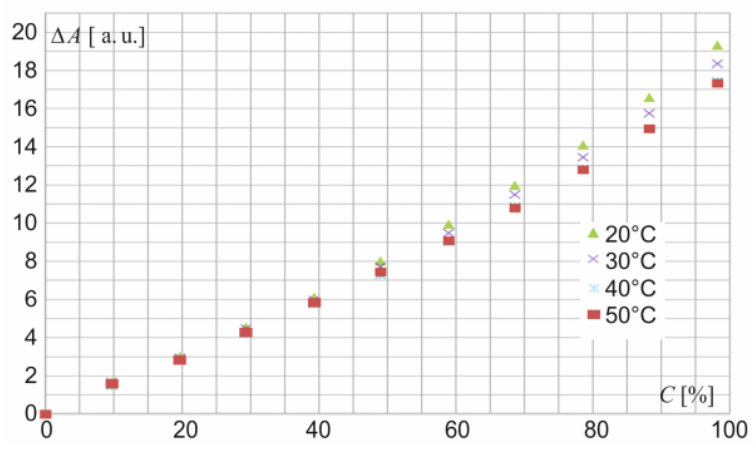

Fig. 5. Illustration of the behaviour of the system on the example of changes of concentration $\mathrm{He}$

The plot of amplitude changes shown in Fig. 5 can be considered linear, especially in the low concentrations range. It is worth noting that the temperature dependence is quite weak and this dependence increases with the concentration, which is basically in accordance with the probabilistic model described here.

\section{CONCLUSIONS AND SUMMARY}

On the basis of the conducted measurements it can be stated that the presented method is suitable for detection of gases of relatively low or high molar masses in relation to the surrounding gas. In this way, it is possible to detect hydrogen, helium, krypton, xenon, etc. in the air at concentrations of several percent. In addition, due to measuring attenuation beside the frequency change, gives the possibility of recognise at least two groups of gases heavier and lighter than gas in the adjacent environment because of different signs of their $\Delta \mathrm{A}$.

However, sensitivity can be increased by increasing the amplitude and, above all, the frequency of the Rayleigh wave. The method is not selective, but it can be useful for monitoring technical installations containing these gases. The main advantage of this type of sensors is their simplicity, very low time constant, high reliability and resistance to ageing processes.

\section{REFERENCES}

1. Jasek K, Pasternak M. The Influence of External Pressure on Resonant Frequency of SAW Resonator. Acta Physica Polonica A. 2015; 127(6):1601-1604. https://doi.org/10.12693/APhysPolA.127.160

2. Jasek K, Neffe S, Pasternak M. SAW sensor for mercury vapour detection. Acta Physica Polonica A. 2012; 122(5):825:827

3. Urbańczyk M. Sensory gazu z akustyczną falą powierzchniową. Wydawnictwo Politechniki Śląskiej, 2011.

4. Mujahid A, Dickert FL. Surface acoustic wave (SAW) for chemical sensing applications of recognition layers. Sensors. 2017;17(2):2716 https://doi.org/10.3390/s17122716

5. Zhu J, Popovics JS, Schubert F. Leaky Rayleigh and Scholte waves at the fluid-solid interface. J. Acoust. 
Soc.Am.2004;116(4). https://doi.org/10.1121/1.1791718.

6. Cheeke JDN. Fundamentals and Applications of Ultrasonic Waves. CRC Press 2002.

7. Mozhaev V, Weihnacht M. Subsonic leaky Rayleigh waves at liquid-solid interfaces, Ultrasonics. 2002;40(18):927-933.

https://doi.org/10.1016/S0041-624X(02)00233-0

8. Borman VD, Krylov SY, Kharitonov AM. Transport phenomena at a gas-solid interface due to propagation of surface sound. Zh. Eksp. Teor. Fiz., Sov. Phys. JETP 1987;92:1668-1683.

9. Chu KW. Transport induced by a surface acoustic wave along a slab. The European Physical Journal - Applied Physics. 2002;18(1):51-56. https://doi.org/10.1051/epjap:2002026

10. Aleksandrov OE, Seleznev VD. Acoustic gas slip induced by surface waves. Journ. of Statist. Phys. 1995; 78:161-167.

11. Pasternak M. Applicability of different SAW oscillators' topologies for high frequency gas sensors construction. Acta Physica Polonica B. 2010; 118(6):1232-1234

12. Filipiak J, Solarz L, Steczko G. Surface acoustic wave vibration sensor electronic system. Acta Physica Polonica A. 2011; 120(4):598-603.

13. Soluch W. SAW Synchronous Multimode Resonator with Gold Electrodes on Quartz. IEEE Trans. on Ultras. Ferroel. and Freq. Control, 2008;55(6):1391-1393, https://doi.org/10.1109/TUFFC.2008.803

14. Jasek K, Miluski W, Pasternak M. A new system for acoustoelectronic gas sensors analysis. Acta Physica Polonica A. 2014;124(3):445:447. https://doi.org/10.12693/APhysPolA.124.445

15. Grabka M, Jasek K, Pasternak M, Miluski W. Stanowisko do badania sensorów $\mathrm{z}$ akustyczną falą powierzchniową. Aparatura Badawcza i Dydaktyczna. 2015; 20(4): 251-258.

Received 2019-06-19

Accepted 2020-01-03

Available online 2020-01-07

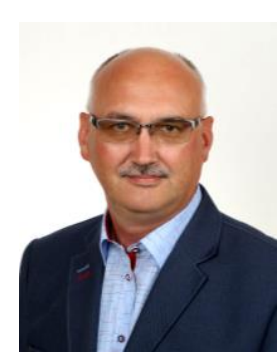

Mateusz PASTERNAK was born in Wadowice, Poland in 1965. Currently he is employed as an professor in the Institute of Radioelectronics, Military University of Technology in Warsaw. His interests involve the surface acoustic wave sensors as well as ultrawideband radar technology. He has published over 100 scientific and technical papers, four handbooks and holds one patent.

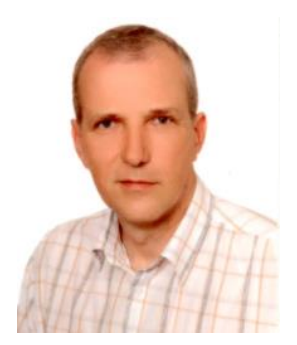

Krzysztof JASEK, Ph.D. in chemistry. Currently he is employed in the Institute of Chemistry, Military University of Technology in Warsaw. His interests involve the analytical chemistry especially chemical sensors.

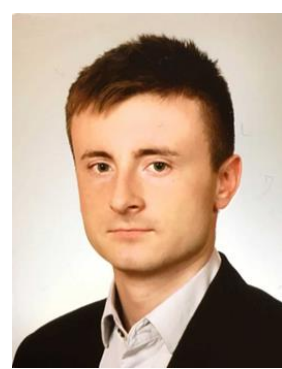

Michal GRABKA was born in 1987 in Tarnobrzeg, Poland. He received his MSc in 2011 from Military University of Technology, Poland. Currently his work is focused on design and development of selective polymeric materials for gas sensor applications. 